\title{
Litter decomposition and nutrient dynamics of ten selected tree species in tropical rainforest of Ebom, southwest Cameroon
}

\author{
Adamu IBRAHIMA ${ }^{1^{*}}$, Antoine D. MVONDO ZE ${ }^{2}$ and Jean Claude NTONGA ${ }^{3}$ \\ ${ }^{I}$ The University of Ngaoundere, Faculty of Sciences, Department of Biological Science, P.O. Box 454 \\ Ngaoundere, Cameroon. \\ ${ }^{2}$ University of Dschang, Faculty of Agronomy and Agricultural Sciences, P.O. Box 234, Dschang, Cameroon. \\ ${ }^{3}$ Institute of Geological and Mining Research, P.O. Box 4110, Yaoundé, Cameroon. \\ *Corresponding author; E-mail: aibrahima@hotmail.com
}

\begin{abstract}
Litter decomposition processes in tropical rainforests are still poorly understood. Leaf litter decomposition and nutrient dynamics of ten contrasting tree species, Entandraphragma utile, Guibourtia tessmannii, Klainedoxa gabonensis, Musanga cecropioides, Panda oleosa, Plagiostyles africana, Pterocarpus soyauxii, Strombosia scheffleri, Vitex grandifolia and Xylopia aethiopica were studied in the tropical rainforest of Ebom, Southwest Cameroon. After 23 weeks of field incubation in litterbags, mass loss of litter samples varied from $24.08 \%$ in E. utile to $92.35 \%$ in V. grandifolia. Decomposition rate constants (k) ranged from 0.014 in M. cecropioides to 0.165 week $^{-1}$ in $V$. grandifolia. The nutrient content in original litter samples also varied widely among species and showed low levels of $\mathrm{Na}, \mathrm{P}$ and $\mathrm{Mg}$, and high levels of $\mathrm{N}, \mathrm{Ca}$ and $\mathrm{K}$. Average nutrient releases was $89.04 \%, 60.80 \%, 46.19 \%, 40.99 \%$ and $24.17 \%$ of mean initial content for $\mathrm{K}, \mathrm{Ca}, \mathrm{Mg}, \mathrm{N}$ and $\mathrm{P}$, respectively. For nutrient-related litter chemistry, correlations with the mass losses at the end of litter incubation were significant $(\mathrm{P}<0.05)$ only for $\mathrm{C}: \mathrm{N}$ ratio, $\mathrm{Mg}$ and $\mathrm{K}$ content, whereas decomposition rate constants were significant only for $\mathrm{K}(\mathrm{P}<0.01)$ and $\mathrm{P}(\mathrm{P}<0.05)$. It can be concluded that litter decomposition is affected by litter chemistry and specific nutrient composition in Ebom tropical rainforest of Cameroon.
\end{abstract}

(c) 2011 International Formulae Group. All rights reserved.

Keywords: Litter decomposition, Litter chemistry, Nutrient dynamics, phytodiversity, Tropical rainforest, Cameroon.

\section{INTRODUCTION}

Litter decomposition represents an important phase of nutrient cycling and carbon fluxes of terrestrial ecosystems (Sun et al., 2004; Berg and Laskowski, 2006). It is during this phase that nutrients, in particular $\mathrm{N}$ and $\mathrm{P}$, immobilized in the litter are partly released and are made available for plants and soil micro-organisms (Begon et al., 2005). Knowledge of the cycling of nutrients through litter decomposition is important for managing the productivity of forest ecosystems, regeneration of seedlings and restoration of soil fertility.

Rates of litter decomposition and nutrient release are often site specific (Edmonds, 1984) and patterns of nutrient release are complex and independent of mass loss (Johnson et al., 1982). The major factors controlling litter decomposition and nutrient 
release in forest ecosystems are temperature and moisture (Cisneros-Dozal, 2007), soil type (Hobbie and Vitousek, 2000), decomposer populations (Mayer, 2008; NegreteYankelevich et al., 2008) and initial litter properties such as $\mathrm{N}$ and $\mathrm{P}$ content, ratios of $\mathrm{C}: \mathrm{N}, \mathrm{C}: \mathrm{P}$ and lignin:N and litter toughness and thickness (McGroddy et al., 2004; Valenzuelasolano et al., 2006). Information on litter decomposition processes in tropical rainforests is relatively poor compared to that of temperate forests and the influence of litter quality on decomposition is not fully understood (Hirobe et al., 2004).

The impact of plant species on litter decomposition and nutrient availability depends on the chemical composition of their litter and varies with development of phase of the forest vegetation (Kimmins, 1987), tree species and groups such as climax and pioneer, evergreen and deciduous species (Knops et al., 2001; van Dam, 2001; Ibrahima et al., 2010). These aspects are particularly prominent in tropical rainforest because of the mosaic development of the vegetation phase and high species diversity (Leigh et al., 2004). The relationships between tree species composition, tree groupings and litter decomposition are not clear because of the heterogeneity of vegetation (Proctor et al., 1983).

The amount of forest area in Cameroon is estimated at 21 Mha, of which about 17.5 Mha are assigned as productive forests (MINFOF, 2005). Forest exploitation has increased over the last three decades, probably as the consequence of CFA Franc devaluation (Eba'a Ayeti, 2000). So, as remedy to the negative impact forest exploitation to biological diversity, the Cameroonian government with the aid of donors strive through research programmes like the Tropenbos Cameroon Programme to develop sustainable management methods and strategies of these forests. This should not only protect the biodiversity but also ensures a sustainable production of the goods and services of these forests at a socially, economically as well as ecologically acceptable levels (Foahom and Jonkers, 1992). The sustainable management of rainforest like that of Cameroon requires, without overlooking the interests of the local inhabitants, knowledge of its structure and functioning, such as phytomass and nutrient cycling, including litter decomposition.

The objective of the present study was to assess litter decomposition and nutrient dynamics of ten dominant and various tree species of Ebom rainforest, and to compare climax and pioneer species. The influence of litter quality on litter decomposition process is also discussed. This study was carried out within the framework of the Tropenbos Cameroon Programme (TCP).

\section{MATERIALS AND METHODS}

\section{Study site}

The study was conducted within the

Tropenbos Cameroon Programme (TCP) research area, which is located in the western portion of the Atlantic Biafrean forest of south Cameroon, lying within the Congo-Guinea refuge. The TCP area is approximately 2000 $\mathrm{km}^{2}$ and bordered by the villages of Lolodorf ( $\left.3^{\circ} 14^{\prime} \mathrm{N}, 10^{\circ} 44^{\prime} \mathrm{E}\right)$ in the north, AdjapEssawo $\left(3^{\circ} 02^{\prime} \mathrm{N}, 10^{\circ} 52^{\prime} \mathrm{E}\right)$ in the east, Akom II $\left(2^{\circ} 48^{\prime} \mathrm{N}, 10^{\circ} 34^{\prime} \mathrm{E}\right)$ in the south, and Bipindi $\left(3^{\circ} 4^{\prime} \mathrm{N}, 10^{\circ} 25^{\prime} \mathrm{E}\right)$ in the west (Van Gemerden and Hazeu, 1999). The bed rock is composed of Precambrian metamorphic as well as old volcanic rocks (Franqueville, 1973). The soil between 50 and $350 \mathrm{~m}$ a.s.l. is a mixture of sand and clay $(<25 \%)$ and is moderately acidic and between 350 and $500 \mathrm{~m}$ a.s.1. it is very clayey (35$70 \%$ ) and strongly acidic (Van Gemerden and Hazeu, 1999). The climate is humid tropical with four seasons: a long dry season (from mid-November to mid-March), a second short dry season (mid-May to mid-August), a short rainy season (mid-March to mid-May), and a long rainy season (mid-August to midNovember). Rainfall decreases progressively to the east of the study area with an annual average of $2836 \mathrm{~mm}$ at Kribi, $2096 \mathrm{~mm}$ at Lolodorf and $1719 \mathrm{~mm}$ at Ebolowa (Ntonga et 
al., 2002). Annual average temperature ranges between 22.9 and $27.5^{\circ} \mathrm{C}$ (Olivry, 1986).

The vegetation is classified as Biafrean Atlantic rainforest rich in Caesalpiniaceae (Letouzey, 1985). The western and central portions of this area with an altitude of slightly less than $700 \mathrm{~m}$ a.s.l. are covered with an evergreen forest, characterised by tall trees that reach heights of about $60 \mathrm{~m}$. The eastern part is mountainous and covered by a submountainous forest with a canopy that varies from 15 to $20 \mathrm{~m}$ height (Van Gemerden and Hazeu, 1999). The forest has been logged during the last decade, especially in the eastern part, with the exception of the mountainous parts. Exploited species are Lophira alata, Erythrophloeum ivorense and Pterocarpus soyauxii. The logging rate was low, averaging $10 \mathrm{~m}^{3} \mathrm{ha}^{-1}$ or about 0.7 tree ha ${ }^{1}$ (Van Gemerden and Hazeu, 1999). At some places in the forest, Bantou people practice shifting agriculture with short fallows (Nounamou and Yemefack, 2001), while Bagyeli Pygmee live from gathering and hunting. Many non-timber forest products such as bushmeat, honey, mushroom, fruits, leaves, seeds and roots are harvested (Van Dijk, 1999).

The experimental site was selected in an undisturbed area of the catchment of Bibo'o Minwo near Ebom and characterized by the absence of recent natural or human disturbance. Relevant characteristics of the site including location, rainfall data and soil physico-chemical characteristics are presented by Van Gemerden and Hazeu (1999). The tree density was about 521 trees $^{-1}{ }^{-1}$ with a basal area of $29.84 \mathrm{~m}^{2} \mathrm{ha}^{-1}$, the diameter classes ranging from 9.4 to $150.0 \mathrm{~cm}$ with a mean diameter of $21.3 \mathrm{~cm}$ (Ibrahima et al., 2002).

\section{Litter collection and selection}

In this study, only freshly fallen leaf litter of the 10 most common and dominant species from the forest was used (representing 82 to $90 \%$ of the total fresh leaf mass). The species used were Entandraphragma utile (Dawe \& Sprague) Sprague (Meliaceae), Guibourtia tessmannii (Harms) J. Leonard
(Caesalpiniaceae), Klainedoxa gabonensis Pierre ex. Engl. (Irvingiaceae), Panda oleosa Pierre (Pandaceae), Plagiostyles africana (Mull. Arg.) Prain (Euphorbiaceae), Pterocarpus soyauxii Taub (Fabaceae), Strombosia scheffleri Engl. (Olacaceae), Vitex grandifolia Gürke (Verbenaceae), Musanga cecropioides R. Brown ex. Tedlie (Cecropiaceae) and Xylopia aethiopica (Dunal) A. Rich (Annonaceae). The first eight species were classified as climax tree or shade-bearer species, M. cecropioides as a pioneer species and Xylopia aethiopica classified as a riverine species, but here we assumed it to be a pioneer. Litter samples were collected fortnightly, except during the long rainy season when litter was collected weekly from 20 litter traps placed in undisturbed forest during a litterfall experiment (Ibrahima et al., 2002). The litter samples were taken to the laboratory in polythene bags and dried in oven-dried at $60^{\circ} \mathrm{C}$ for $48 \mathrm{~h}$. Leaf litter was sorted by species and only this material after drying was used for the decomposition experiment.

\section{Litter decomposition experiment}

The litterbag method described by Bocock et al. (1960) and Ibrahima (1995) was used. Litterbags consisted of nylon material with a $1 \mathrm{~mm}$ mesh and were sized according to litter type to avoid leaf material compression and prevent the creation of artificial conditions within the litterbags. The choice of litterbag dimension and mesh sizes was based on other studies in tropical forests (Brouwer, 1996; Ibrahima et al., 2002; van Dam, 2001). In total, 180 litterbags (6 sampling dates x 3 replications $\times 10$ species) were filled, each with $5 \pm 0.01 \mathrm{~g}$ of litter and placed on top of the soil, from $18^{\text {th }}$ January to $29^{\text {th }}$ June 2001. Three litterbags per species were collected at 2, 4, 6, 9, 14 and 23 week intervals and transported to the laboratory, roots, fauna, and soil particles were removed from the litterbags. The dry mass of samples in each litterbag was determined after oven drying at $60{ }^{\circ} \mathrm{C}$ to constant mass. To determine initial dry mass and nutrient content, three 
supplementary litter samples of each species were weighed and dried at $60{ }^{\circ} \mathrm{C}$ to constant mass. The residual dry mass as percentage of original dry mass in each litterbag was determined using the equation $\left(\mathrm{DM}_{\mathrm{t}} / \mathrm{DM}_{0}\right) \mathrm{x}$ 100 , where $\mathrm{DM}_{0}$ is the original dry mass and $\mathrm{DM}_{\mathrm{t}}$ is the residual dry mass at time $\mathrm{t}$.

\section{Chemical analysis}

Samples were ground into powder through a Culatti micro hammer Mill grinder equipped with a $1 \mathrm{~mm}$ link filter. Ground samples were first mineralised by passing the powder through a furnace at $550{ }^{\circ} \mathrm{C}$ for 40 mins. The ashes were collected with a diluted $\mathrm{HNO}_{3}$ solution for nutrient analysis. Calcium (Ca) and magnesium $(\mathrm{Mg})$ were determined by atomic absorption spectrophotometry; potassium (K) and sodium $(\mathrm{Na})$ by flame spectrophotometry; phosphorous (P) by vanado - molybdate colorimetry. Nitrogen $(\mathrm{N})$ was analyzed using the Kjeldhal method and titrated with sulphuric acid at $0.01 \mathrm{~N}$. The carbon content was detected by oxidation with potassium dichromate after digestion in the presence of oxygenated water. Some samples from M. cecropioides, S. scheffleri and $X$. aethiopica from the third and fourth collection could not be analyzed.

\section{Statistical analysis}

The litter decomposition rate constant (k) for each species was estimated using the simple negative exponential decay function (Olson, 1963):

$\mathrm{DMR}=100 \mathrm{e}^{-\mathrm{kt}}$

Where DMR is the litter dry mass remaining.

The $\mathrm{k}$ value was used to calculate turnover time $(1 / \mathrm{k})$ and the time required for $50 \%$ decomposition or the half-life of litter in the litterbag $\left(\mathrm{t}_{0.5}\right.$, Bockheim et al., 1991):

$\mathrm{t}_{0.5}=\mathrm{Ln}(0.5) /-\mathrm{k}=0.693 /-\mathrm{k}$.

The remaining nutrient content of litter was calculated as a percentage of the initial content using the following equation (Bockheim et al., 1991):

$\mathrm{QR}=\left(\mathrm{C}_{\mathrm{t}} / \mathrm{C}_{0}\right) *\left(\mathrm{DM}_{\mathrm{t}} / \mathrm{DM}_{0}\right) * 100$

Where $\mathrm{QR}$ is the nutrient amount remaining (\%); $\mathrm{C}_{\mathrm{t}}$ and $\mathrm{C}_{0}$ are respectively nutrient content at time $\mathrm{t}$ and at time $0 ; \mathrm{DM}_{\mathrm{t}}$ and $\mathrm{DM}_{0}$ are dry mass at time $\mathrm{t}$ and at the initial time.

Before performing any statistical analysis, all variables were tested for normality and if necessary (usually) log transformed. Comparisons among species of dry mass remaining (DMR) and nutrient content after 23 weeks of incubation were made using one-way ANOVA followed by Scheffe's test at 5\% if differences were significant. A multiple comparison among the decay rate constants (k) was also done using the T'method (Sokal and Rohlf, 1981). Linear regression was calculated between original nutrient content and final DMR (at 23 weeks) or decomposition rate constant $(\mathrm{k})$. Nutrient content at the last incubation (23 weeks of incubation) was compared to those measured in the original litter for each species by Students t-test. The loss of nutrients was calculated as the difference between the original absolute amount and the final amount of each nutrient and this difference was also expressed as percentage of original amount (\%) if the Students t-test was significant. These tests were conducted using SX software statistic (version 4.0, Analytical software 1992).

\section{RESULTS}

\section{Dynamics of dry mass of remaining litter}

At the end of the incubation period, the dry mass remaining (DMR) varied significantly among species $(\mathrm{F}=5.39, \mathrm{P}<$ 0.01 ), from $7.6 \%$ in $V$. grandifolia to nearly $80 \%$ of initial dry mass in E. utile, thus corresponding to a loss ranging from 24 to $92 \%$ in the same species (Table 1). Generally, the greatest and the smallest mass loss were found in climax species. No significant difference $(\mathrm{P}>0.05)$ was found between climax $(44.74 \pm 8.34 \%)$ and pioneer species $(55.46 \pm 5.08 \%)$ according to their DMR.

The dynamics of DMR varied according to species (Figure 1). Decomposition was fast at the beginning of the incubation period for all the species apart from $K$. gabonensis and S. scheffleri. This loss decreased with time. The loss of leaf litter 
mass was greatest in $V$. grandifolia, and lowest in E. utile and those of other species were intermediate.

A simple exponential function was used to determine $\mathrm{k}$ and the corresponding half-life of decomposition. The coefficients of determination were all highly significant $(\mathrm{P}<$ $0.001)$, although they varied among species (Table 1). The values of $\mathrm{k}$ ranged from 0.04 for $M$. cecropioides to 0.165 week $^{-1}$ for $V$. grandifolia, corresponding to $\mathrm{t}_{0.5}$ of 49.5 and 4.2 weeks for these two species. The rate of litter decomposition of climax species overlapped with the range of pioneer species, but the litter decay constants of the last group were ranged among the lowest.

\section{Changes in carbon and nutrient content}

The original carbon and nutrient contents varied significantly according to nutrient and species (Table 2). The original $\mathrm{Mg}, \mathrm{Na}$ and $\mathrm{P}$ contents were lower than those of $\mathrm{C}, \mathrm{N}, \mathrm{Ca}$ and $\mathrm{K}$ for all the litters, except $\mathrm{Ca}$ in the original litter of G. tessmannii $(0.67 \mathrm{~g}$ $\mathrm{kg}^{-1}$ ) and $\mathrm{K}$ in the original litter of $M$. cecropioides $\left(0.89 \mathrm{~g} \mathrm{~kg}^{-1}\right)$.

About 23 weeks after incubation of the litters in situ, the nutrients release varied with plant species and nutrients (Table 3). Nitrogen was released in all the litters, except in the litter of E. utile that continued to immobilize it, 23 weeks after incubation. This immobilization was not significant compared to the original value. For the other species, the release of $\mathrm{N}$ was only significant relative to the original value for $V$. grandifolia, $P$. africana, S. scheffleri, G. tessmannii, $P$. soyauxii and $X$. aethiopica, with the highest release rate for $V$. grandifolia $(90.11 \%)$, the lowest one for S. scheffleri (25.54\%), while the corresponding $\mathrm{N}$ losses were 52.46 and $11.76 \mathrm{mg}$ respectively.

Ca was released by all the litters, 23 weeks after incubation in situ, unlike E. utile, that continued to immobilize this nutrient (Table 3). The release of $\mathrm{Ca}$ was significant, except for the M. cecropioides litter. The highest release of $\mathrm{Ca}$ was found in $V$. grandifolia and the lowest one in $K$. gabonensis, with the release rate of 99.62 and $50.78 \%$, and the corresponding losses of 10.39 and $4.56 \mathrm{mg}$ respectively.

$\mathrm{Mg}$ was still immobilized in the litters of P. oleosa and G. tessmannii 23 weeks after incubation in situ. This immobilization was significant for G. tessmannii, with a value of $2.78 \mathrm{mg}$ and the rate corresponding of $992.86 \%$ (Table 3). Conversely, the other species released significantly $\mathrm{Mg}$, excepted $E$. utile and $M$. cecropioides in which the release was not significant. The release rate of the six remaining species varied from 29.36 in $S$. scheffleri to $98.28 \%$ in $V$. grandifolia, with the corresponding losses of 0.32 and $4.56 \mathrm{mg}$ respectively.

$\mathrm{K}$ was the only nutrient released by all the litters at 23 weeks of incubation (Table 3), but the release was not significant compared to the original values in $E$. utile and $M$. cecropioides. The highest release was found in $V$. grandifolia and the lowest one in $K$. gabonensis, at respective rates of 99.76 and $75.76 \%$ and with corresponding losses of 33.32 and $14.22 \mathrm{mg}$.

$\mathrm{Na}$ was the less released nutrient after 23 weeks of incubation in situ (Table 3). Only $V$. grandifolia and $X$. aethiopica showed release of $\mathrm{Na}$, but this release was significant compared to the initial value only in $V$. grandifolia, with a rate of $99.17 \%$ and a loss of $0.12 \mathrm{mg}$. Na was still at the immobilization phase for other species, 23 weeks after incubation. This immobilization reached $600 \%$ in $M$. cecropioides, with an increase of $0.06 \mathrm{mg}$. The lowest increase of $\mathrm{Na}(0.02 \mathrm{mg})$ was found in S. scheffleri at a rate of $100 \%$.

$\mathrm{P}$ was released by all the litters at 23 weeks of incubation, except for P. oleosa, $G$. tessmannii and E. utile, in which $\mathrm{P}$ was still at the immobilization phase (Table 3). The release of $\mathrm{P}$ was significant only in $V$. grandifolia $(78.73 \%)$, P. africana $(31.28 \%)$ and $X$. aethiopica $(69.21 \%)$ with respective losses of 2.49, 0.66 and $2.36 \mathrm{mg}$.

Among species, the litter of $V$. grandifolia released the highest quantities of all the nutrients after 23 weeks of incubation in situ, with rate reaching $99 \%$ for $\mathrm{Ca}, \mathrm{K}$ and 
$\mathrm{Na}$ (Table 3). The lowest quantities of nutrients were from the litters of $S$. scheffler for $\mathrm{N}$ and $\mathrm{Mg}$, of $K$. gabonensis for $\mathrm{Ca}$ and $\mathrm{K}$, and of $P$. africana for $\mathrm{P}$, with respective rates of $25.54 \%, 29.36 \%, 50.78 \%, 75.76 \%$, and $31.28 \%$. Globally, the nutrients were classified according to their mean release rate as follow: $\mathrm{K}(89.04 \%)>\mathrm{Ca}(60.80 \%)>\mathrm{Mg}(46.19 \%)>$ $\mathrm{N}(40.99 \%)>\mathrm{P}(24.17 \%)$.

Dynamics of litter nutrients during the course of decomposition

Nutrients showed different dynamics during the 23 weeks of litter decomposition (Figures 2 and 3). However, three groups of nutrients were distinguished according to their dynamics. In the first group to which belong $\mathrm{N}$ and $\mathrm{Mg}$, the immobilization phase was located between 2 and 14 weeks of incubation depending on the species. At the end of the experiment, the two nutrients were released by all the litters at rates varying with species (Figure 2).

$\mathrm{Ca}$ and $\mathrm{K}$ were the only nutrients released from the beginning of incubation to the end of the experiment for all the litter types, with rates varying according to species, except that $\mathrm{Ca}$ slightly increased in the $X$. aethiopica litter during the first two weeks of incubation before the beginning of mineralization (Figures 2 and 3). The patterns of release of both nutrients ( $\mathrm{Ca}$ and $\mathrm{K}$ ) were similar to the litter mass loss.

The immobilization phase of the last group, constituted by $\mathrm{Na}$ and $\mathrm{P}$ was extended on all the incubation period (Figure 3). At the end of the experiment, the immobilization of Na continued in the $P$. africana, P. oleosa, $E$. utile, $K$. gabonensis and $P$. soyauxii litters and that of $\mathrm{P}$ in the E. utile, K. gabonensis and $M$. cecropioides litters.

Correlations between DMR, constants (k) and initial nutrient contents

Significant correlations were found between DMR after 23 weeks of incubation and initial chemistry of litter (Figures 4 and 5). DMR was related to $\mathrm{C}: \mathrm{N}$ ratio (Figure 4). The increase of $\mathrm{C}: \mathrm{N}$ ratio in the initial litter led to slowing litter mass loss (or increasing DMR). It was also related to $\mathrm{Mg}$ and $\mathrm{K}$ contents of the initial litter, if the data of $K$. gabonensis as outlier were removed (Figure $5 \mathrm{a}$ and $\mathrm{b}$ ). Conversely to $\mathrm{C}: \mathrm{N}$ ratio, litter mass loss increased with increased $\mathrm{Mg}$ and $\mathrm{K}$ contents. Similarly, litter decomposition rate constant (k) significantly and positively correlated with the initial $\mathrm{K}$ and $\mathrm{P}$ contents, when data of $V$. grandifolia as outlier were removed (Figure 6a and b) and the nutrients influenced positively litter decomposition.

Table 1: Dry mass remaining (\% of initial mass) after 23 weeks of incubation.

\begin{tabular}{lllll}
\hline Species & DMR $(\%)$ & $\mathbf{k}\left(\mathbf{w e e k}^{-\mathbf{1}}\right)$ & $\mathbf{R}^{\mathbf{2}}$ & $\left.\mathbf{( t}_{\mathbf{0 . 5}}\right)$ \\
\hline V. grandifolia & $7.65(3.44) \mathrm{a}$ & $0.165(0.031) \mathrm{a}$ & 0.779 & 4.20 \\
G. tessmannii & $29.58(15.66) \mathrm{ab}$ & $0.065(0.007) \mathrm{b}$ & 0.820 & 10.66 \\
P. soyauxii & $32.78(23.72) \mathrm{ab}$ & $0.059(0.006) \mathrm{b}$ & 0.877 & 11.75 \\
P. Africana & $34.56(5.58) \mathrm{ab}$ & $0.050(0.003) \mathrm{b}$ & 0.939 & 13.86 \\
S. scheffleri & $42.45(11.63) \mathrm{bc}$ & $0.030(0.003) \mathrm{c}$ & 0.785 & 23.10 \\
P. oleosa & $65.55(24.69 \mathrm{~cd}$ & $0.027(0.002) \mathrm{c}$ & 0.813 & 25.67 \\
K. gabonensis & $69.59(4.46) \mathrm{cd}$ & $0.026(0.002) \mathrm{c}$ & 0.916 & 26.65 \\
E. utile & $75.92(7.41) \mathrm{d}$ & $0.016(0.001) \mathrm{d}$ & 0.739 & 43.31 \\
$X$. aethiopica & $50.38(4.44) \mathrm{bcd}$ & $0.022(0.001) \mathrm{c}$ & 0.903 & 31.50 \\
M. cecropioides & $60.54(28.19) \mathrm{cd}$ & $0.014(0.002) \mathrm{d}$ & 0.508 & 49.50 \\
\hline
\end{tabular}

DMR (Dry mass remaining) fitted to simple exponential model: DMR $=100 * \mathrm{e}^{-\mathrm{kt}}$, where $\mathrm{k}$ and $\mathrm{t}$ are respectively decomposition rate constant and time. $\mathrm{SE}$ in parenthesis. $\mathrm{t}_{0.5}$ : half live.

Lower case letters refer to mean comparison. Values with the same lower case letters indicate that species are not significantly different. 
Table 2: Carbon and nutrient content $\left(\mathrm{g} \mathrm{kg}^{-1}\right)$ of 10 rainforest tree species prior to incubation.

\begin{tabular}{|c|c|c|c|c|c|c|c|c|}
\hline Species & $\mathrm{C}$ & $\mathbf{N}$ & $\mathbf{C N}$ & $\mathrm{Ca}$ & Mg & $\mathbf{K}$ & $\mathbf{N a}$ & $\mathbf{P}$ \\
\hline V. grandifolia & $480(0.35) \mathrm{e}$ & $17.15(0.30) \mathrm{b}$ & $27.99(0.56) \mathrm{de}$ & $1.66(0.34) b$ & $0.84(0.33)$ & $6.02(0.35) \mathrm{abc}$ & $0.005(0.003)$ & $0.45(0.37)$ \\
\hline P. Africana & $610(0.42) b$ & $32.40(0.41) \mathrm{a}$ & $18.83(0.23) \mathrm{e}$ & $2.14(0.33) b$ & $0.95(0.42)$ & $6.84(0.40) a b$ & $0.025(0.04)$ & $0.65(0.46)$ \\
\hline S. scheffleri & $430(0.17) \mathrm{f}$ & $18.69(0.18) b$ & $23.01(0.22)$ ef & $4.89(0.18) \mathrm{a}$ & $0.73(0.20)$ & $3.78(0.18) \mathrm{cd}$ & $0.007(0.001)$ & $0.68(0.25)$ \\
\hline P. oleosa & $640(0.14) \mathrm{a}$ & $14.49(0.15) \mathrm{c}$ & $44.17(0.42) b c$ & $1.29(0.13) b$ & $0.56(0.20)$ & $2.61(0.10) \mathrm{de}$ & $0.007(0.001)$ & $0.45(0.16)$ \\
\hline G. tessmannii & $210(0.26) \mathrm{h}$ & $17.01(0.25) \mathrm{b}$ & $29.98(0.18) \mathrm{de}$ & $0.67(0.27) b$ & $0.46(0.30)$ & $7.59(0.26) \mathrm{ab}$ & $0.006(0.003)$ & $0.74(0.36)$ \\
\hline P. soyauxii & $540(0.50) \mathrm{c}$ & $13.37(0.51) \mathrm{c}$ & 40.39 (1.40) bc & $1.88(0.50) \mathrm{b}$ & $0.57(0.56)$ & $8.22(0.52) \mathrm{a}$ & $0.005(0.004)$ & $0.64(0.54)$ \\
\hline E. utile & $640(0.58) \mathrm{a}$ & $13.65(0.59) \mathrm{c}$ & $46.89(1.95) \mathrm{ab}$ & $1.87(0.58) \mathrm{b}$ & $0.39(0.25)$ & $3.92(0.58) \mathrm{cd}$ & $0.007(0.005)$ & $0.63(0.60)$ \\
\hline X. aethiopica & $520(0.46) \mathrm{d}$ & $10.57(0.47) \mathrm{de}$ & $49.20(2.11) \mathrm{ab}$ & $1.83(0.45) b$ & $0.25(0.16)$ & $1.89(0.46) \mathrm{de}$ & $0.005(0.004)$ & $0.40(0.36)$ \\
\hline M. cecropioides & $420(0.16) \mathrm{g}$ & $12.25(0.17) \mathrm{cd}$ & $34.28(0.42) \mathrm{cd}$ & $2.72(0.15) \mathrm{ab}$ & $0.06(0.01)$ & $0.89(0.16) \mathrm{e}$ & $0.005(0.002)$ & $0.34(0.20)$ \\
\hline$F$ & $724.64 * * *$ & $432.62 * * *$ & $112.11 * * *$ & $12.92 * * *$ & $0.89 \mathrm{~ns}$ & $63.46^{* * * *}$ & $0.37 \mathrm{~ns}$ & $0.20 \mathrm{~ns}$ \\
\hline
\end{tabular}

the same lower letters indicate that species are not significantly different. 
A. IBRAHIMA et al. / Int. J. Biol. Chem. Sci. 5(1): 11-27, 2011

Table 3: Mean differences in nutrient amounts between the initial litter and the one obtained after 23 weeks of incubation, expressed in (mg).

\begin{tabular}{|c|c|c|c|c|c|c|c|c|c|c|c|c|}
\hline \multirow[t]{2}{*}{ Nutrients } & & \multicolumn{8}{|c|}{ Climax species } & \multicolumn{2}{|c|}{ Pioneer species } & \multirow[t]{2}{*}{$\mathbf{F}$} \\
\hline & & V. grandifolia & P. africana & S. Scheffleri & P. oleosa & $\begin{array}{l}\text { G. } \\
\text { tessmannii }\end{array}$ & P. Soyauxii & K. abonensis & E. utile & X. aethiopica & M. cecropioides & \\
\hline \multirow[t]{5}{*}{$\mathrm{N}$} & Qi & $58.22(17.05)$ & $67.14(4.30)$ & $46.05(3.46)$ & $43.68(5.47)$ & $57.09(4.33)$ & $81.75(6.11)$ & $65.38(7.63)$ & $57.69(50.25)$ & $78.41(3.19)$ & $38.55(33.41)$ & 8.57 *** \\
\hline & Qf & $5.76(2.64)$ & $30.24(4.89)$ & $34.29(2.75)$ & $35.93(2.12)$ & $33.29(14.43)$ & $33.52(24.16)$ & $58.25(20.47)$ & $64.92(6.12)$ & $15.87(8.08)$ & $38.43(9.51)$ & $6.21 * * *$ \\
\hline & $\mathrm{t}$ & $15.30 * * *$ & $9.82 * * *$ & $4.61 *$ & $2.29 \mathrm{~ns}$ & $2.93 *$ & $3.35^{*}$ & $0.57 \mathrm{~ns}$ & $0.25 \mathrm{~ns}$ & $12.47 * * *$ & $0.01 \mathrm{~ns}$ & \\
\hline & $+/-$ & -52.46 & -36.90 & -11.76 & -7.75 & -23.80 & -48.23 & -7.13 & +7.23 & -62.54 & -0.12 & \\
\hline & $\%$ & 90.11 & 54.96 & 25.54 & ND & 41.69 & 59.00 & ND & ND & 79.76 & ND & \\
\hline \multirow[t]{5}{*}{$\mathrm{Ca}$} & Qi & $10.43(1.12)$ & $5.99(0.38)$ & $7.97(0.60)$ & $12.35(1.55)$ & $12.65(0.96)$ & $7.93(0.59)$ & $8.98(1.05)$ & $15.08(13.14)$ & $3.07(0.12)$ & $5.43(4.71)$ & $2.03 \mathrm{~ns}$ \\
\hline & Qf & $0.04(0.02)$ & $0.20(0.03)$ & $2.52(0.20)$ & $2.71(1.57)$ & $3.22(1.40)$ & $1.00(0.72)$ & $4.42(1.55)$ & $17.82(1.68)$ & $0.71(0.36)$ & $2.59(0.64)$ & 75.89 *** \\
\hline & $\mathrm{t}$ & $16.01 * * *$ & $26.06 * * *$ & $14.94 * * *$ & $7.56^{* *}$ & $9.63 * * *$ & $12.86 * * *$ & $4.22 *$ & $0.36 \mathrm{~ns}$ & $10.67 * * *$ & $1.04 \mathrm{~ns}$ & \\
\hline & $+/-$ & -10.39 & -5.79 & -5.45 & -9.64 & -9.43 & -6.93 & -4.56 & +2.74 & -2.36 & -2.84 & \\
\hline & $\%$ & 99.62 & 96.66 & 68.38 & 78.06 & 74.55 & 87.39 & 50.78 & ND & 76.87 & $\mathrm{ND}$ & \\
\hline \multirow[t]{5}{*}{$\mathrm{Mg}$} & Qi & $4.64(0.50)$ & $2.57(0.09)$ & $1.09(0.08)$ & $0.67(0.08)$ & $0.28(0.02)$ & $4.00(0.30)$ & $1.84(0.22)$ & $2.24(1.95)$ & $2.12(0.09)$ & $1.64(1.42)$ & $9.03 * * *$ \\
\hline & Qf & $0.08(0.04)$ & $1.70(0.28)$ & $0.77(0.06)$ & $1.68(1.87)$ & $3.06(1.33)$ & $0.86(0.62)$ & $0.77(0.27)$ & $1.45(0.14)$ & $0.18(0.09)$ & $0.77(0.19)$ & $3.94 * *$ \\
\hline & $\mathrm{t}$ & $15.76 * * *$ & $4.69 * *$ & $5.35 * *$ & $0.94 \mathrm{~ns}$ & $3.63 *$ & $7.87 * *$ & $5.38 * *$ & $0.69 \mathrm{~ns}$ & $26.26 * * *$ & $1.05 \mathrm{~ns}$ & \\
\hline & $+/-$ & -4.56 & -0.87 & -0.32 & +1.01 & +2.78 & -3.14 & -1.07 & -0.79 & -1.94 & -0.87 & \\
\hline & $\%$ & 98.28 & 33.85 & 29.36 & ND & 992.86 & 78.50 & 58.15 & ND & 91.51 & ND & \\
\hline \multirow[t]{5}{*}{ K } & Qi & $33.40(3.60)$ & $12.08(0.78)$ & $8.24(0.62)$ & $26.98(3.38)$ & $15.15(1.15)$ & $28.67(2.14)$ & $18.77(2.19)$ & $11.67(10.16)$ & $34.99(1.42)$ & $23.69(20.53)$ & $4.85 * *$ \\
\hline & Qf & $0.08(0.04)$ & $2.44(0.39)$ & $1.97(0.16)$ & $1.72(1.42)$ & $3.12(1.35)$ & $1.76(1.27)$ & $4.55(1.60)$ & $4.92(0.46)$ & $0.75(0.38)$ & $2.11(0.52)$ & $7.83 * * *$ \\
\hline & $\mathrm{t}$ & $16.03 * * *$ & $19.22 * * *$ & $17.01 * * *$ & $11.93 * * *$ & $11.74 * * *$ & $18.73 * * *$ & $9.08 * *$ & $1.15 \mathrm{~ns}$ & $40.27 * * *$ & $1.82 \mathrm{~ns}$ & \\
\hline & $+/-$ & -33.32 & -9.64 & -6.27 & -25.26 & -12.03 & -26.86 & -14.22 & -6.75 & -34.24 & -21.58 & \\
\hline & $\%$ & 99.76 & 79.80 & 76.09 & 93.62 & 79.41 & 93.86 & 75.76 & ND & 97.86 & ND & \\
\hline \multirow[t]{5}{*}{$\mathrm{Na}$} & Qi & $0.120(0.01)$ & $0.032(0.00)$ & $0.023(0.00)$ & $0.035(0.00)$ & $0.021(0.00)$ & $0.023(0.00)$ & $0.034(0.00)$ & $0.022(0.01)$ & $0.029(0.001)$ & $0.014(0.01)$ & $38.19 * * *$ \\
\hline & Qf & $0.001(0.00)$ & $0.041(0.01)$ & $0.038(0.00)$ & $1.183(1.94)$ & $0.080(0.03)$ & $0.048(0.03)$ & $0.093(0.03)$ & $0.081(0.01)$ & $0.020(0.010)$ & $0.074(0.02)$ & $1.03 \mathrm{~ns}$ \\
\hline & $\mathrm{t}$ & $16.48 * * *$ & $2.27 \mathrm{~ns}$ & $7.89 * *$ & $1.30 \mathrm{~ns}$ & $2.91 *$ & $1.28 \mathrm{~ns}$ & $3.12 *$ & $4.96 * *$ & $1.69 \mathrm{~ns}$ & $4.59 *$ & \\
\hline & $+/-$ & -0.12 & +0.01 & +0.02 & +1.14 & +0.06 & +0.05 & +0.06 & +0.06 & -0.01 & +0.06 & \\
\hline & $\%$ & 99.17 & ND & 100 & ND & 300 & ND & 200 & 300 & ND & 600 & \\
\hline \multirow[t]{5}{*}{$\mathrm{P}$} & Qi & $3.16(0.34)$ & $2.11(0.01)$ & $1.73(0.13)$ & $2.17(0.27)$ & $1.59(0.12)$ & $2.17(0.16)$ & $2.99(0.35)$ & $3.16(0.28)$ & $3.41(0.14)$ & $2.75(0.09)$ & $24.22 * * *$ \\
\hline & Qf & $0.67(0.31)$ & $1.45(0.24)$ & $1.64(0.13)$ & $2.27(0.17)$ & $1.98(0.86)$ & $1.25(0.90)$ & $2.85(1.00)$ & $4.13(0.39)$ & $1.05(0.53)$ & $1.85(0.46)$ & $8.37 * * *$ \\
\hline & $\mathrm{t}$ & $9.45 * * *$ & $4.16^{*}$ & $0.82 \mathrm{~ns}$ & $0.46 \mathrm{~ns}$ & $0.78 \mathrm{~ns}$ & $1.74 \mathrm{~ns}$ & $0.23 \mathrm{~ns}$ & $2.71 \mathrm{~ns}$ & $7.42 * *$ & $2.63 \mathrm{~ns}$ & \\
\hline & $+/-$ & -2.49 & -0.66 & -0.09 & +0.10 & +0.39 & -0.92 & -0.14 & +0.97 & -2.36 & -0.90 & \\
\hline & $\%$ & 78.73 & 31.28 & ND & ND & ND & ND & ND & ND & 69.21 & ND & \\
\hline
\end{tabular}

Standard error in the parentheses. Qi and Qf are nutrient amounts of the original and final litters (mg); ND: not determined, $+/$ - are gain or loss of nutrients. *** $\mathrm{P}<0.001, * * \mathrm{P}<0.01, * \mathrm{P}<0.05$ and $\mathrm{ns}$ : not significant 
A. IBRAHIMA et al. /Int. J. Biol. Chem. Sci. 5(1): 11-27, 2011

Table 4: Mass losses in percentage of original mass and litter decay constants $(\mathrm{k})$ of litter decomposition of some humid tropical forests.

\begin{tabular}{|c|c|c|c|}
\hline Localisation & Mass losses (\%) & k $\left(\right.$ year $\left.^{-1}\right)$ & Sources \\
\hline Cameroon & $24.08-92.35$ & $0.73-8.58$ & This study $^{2}$ \\
\hline Cameroon & - & $1.6-4.2$ & Songwe et al. (1995) \\
\hline Guyana & $24-55$ & $0.7-1.5$ & Brouwer $(1996)^{3}$ \\
\hline Guyana & 30 & 0.65 & van Dam $(2001)^{4}$ \\
\hline Amazon (Brazil) & $49.98^{*}$ & $1.5-5.5$ & Didham $(1998)^{5}$ \\
\hline Amazon (Mixed forest) & - & $0.34-3.68$ & Medina and Cuevas (1989) \\
\hline Amazon (high Caating) & - & $0.62-0.93$ & Medina and Cuevas (1989) \\
\hline Amazon (low Caatinga) & - & $0.21-0.38$ & Medina and Cuevas (1989) \\
\hline Amazon & - & $0.58-5.10$ & Cuevas and Medina (1988) \\
\hline Amazon (brazil) & & $1.81-1.90$ & Luizão et al. (1998) ${ }^{1}$ \\
\hline Sri-Lanka & 63 & 0.9 & Maheswaran and Gunatilleke (1988) \\
\hline Porto Rico & $75.8-80.80$ & $1.42-1.65$ & Zou et al. (1995) \\
\hline Sarawak & $50-65$ & - & Anderson et al. (1983) ${ }^{1}$ \\
\hline Venezuela & 14 & - & Chacón and Dezzeo (2007) \\
\hline
\end{tabular}

Source: Brouwer (1996): ¿2 estimated values in 23 weeks, in 5 months; in 230 days and ${ }^{3}$ in 11 weeks.

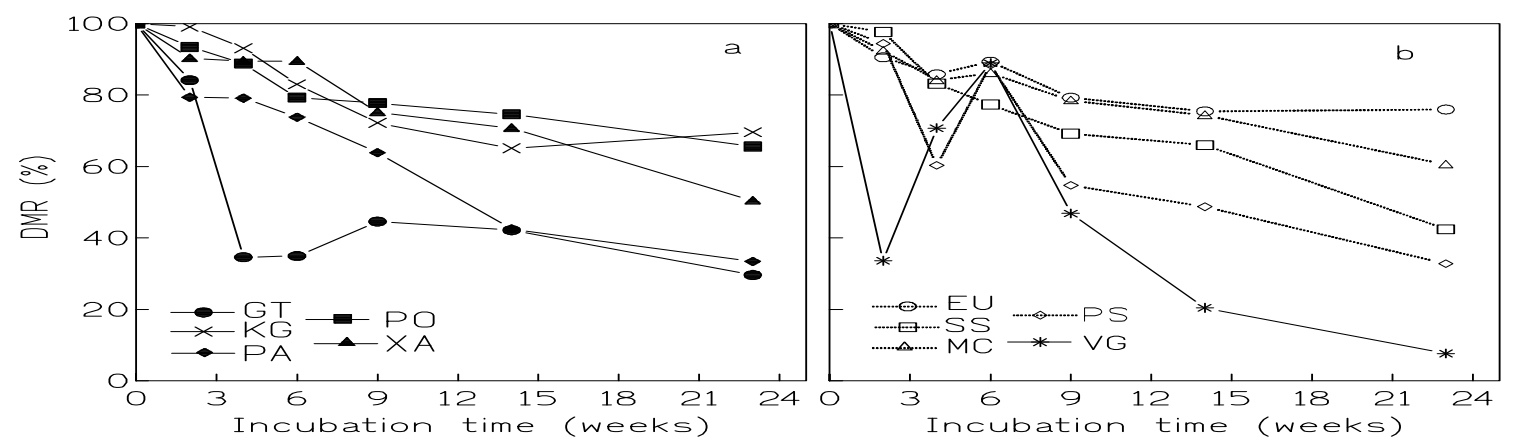

Figure 1: Dry mass remaining (\%) from 10 tree species (five species per graph) during a time course of 23 weeks of litter decomposition. a) G. tessmannii (GT), $K$. gabonensis (KG), P. africana (PA), X. aethiopica (XA) and P. oleosa (PO), and b) E. utile (EU), S. scheffleri (SS), P. soyauxii (PS), M. cecropioide (MC) and V.

grandifolia $(\mathrm{VG})$. 


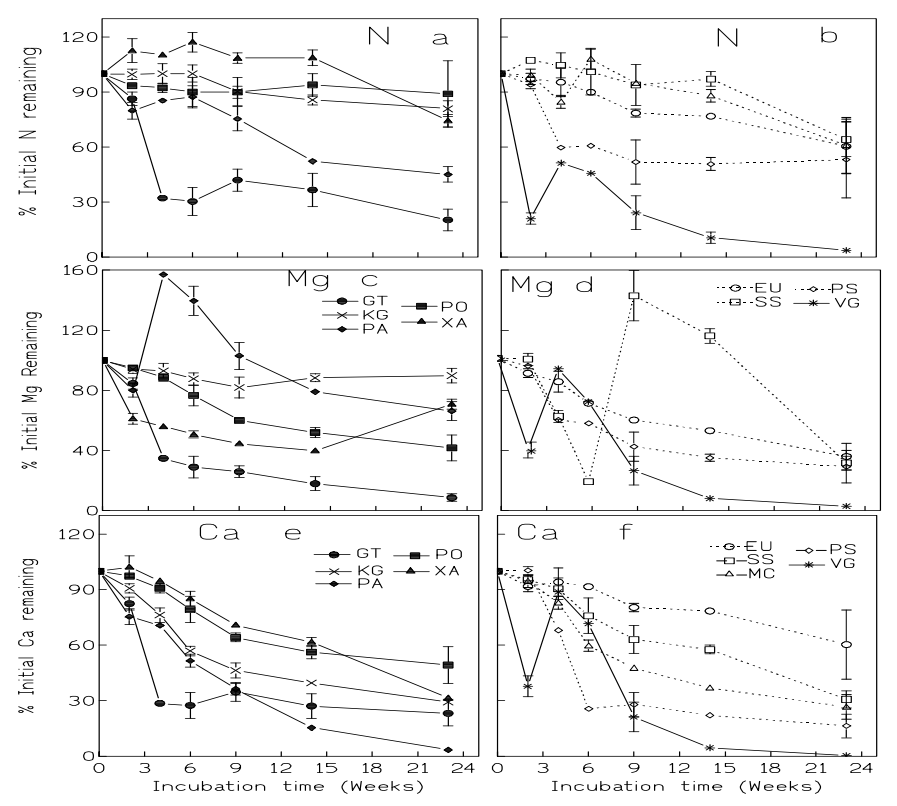

Figure 2: Nutrients (a, b) N, (c, d) Mg and (e, f) Ca remaining (\%) in decomposing leaf litter from 10 tree species (five species per graph) during a time course of 23 weeks of litter decomposition. a) G. tessmannii (GT), K. gabonensis (KG), P. africana (PA), X. aethiopica (XA) and P. oleosa (PO) and b) E. utile (EU), S. scheffleri (SS), P. soyauxii (PS), M. cecropioide (MC) and V. grandifolia (VG). Error bars (SE).

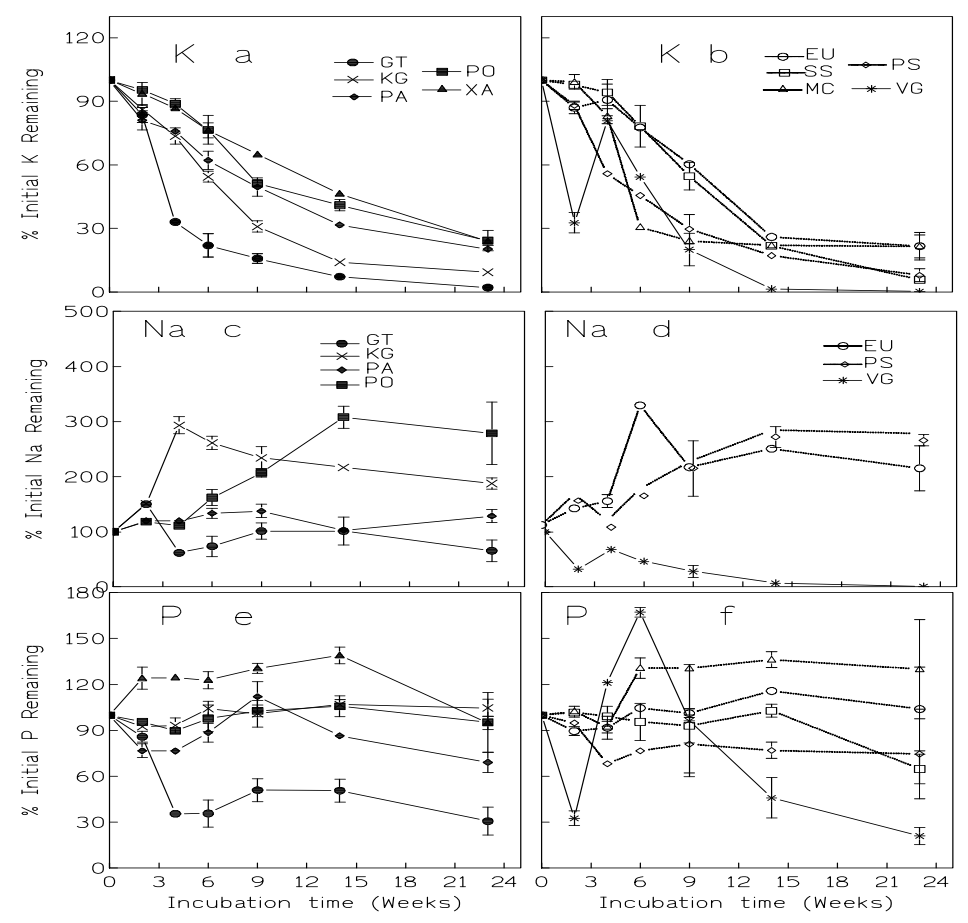

Figure 3: Nutrients (a, b) K, (c, d) $\mathrm{Na}$ and (e, f) P remaining (\%) in decomposing leaf litter from 10 tree species (five species per graph) during a time course of 23 weeks of litter decomposition. a) $G$. tessmannii (GT), K. gabonensis (KG), P. africana (PA), X. aethiopica (XA) and P. oleosa (PO) and b) E. utile (EU), $S$. scheffleri (SS), P. soyauxii (PS), M. cecropioide (MC) and V. grandifolia (VG). Error bars (SE). 


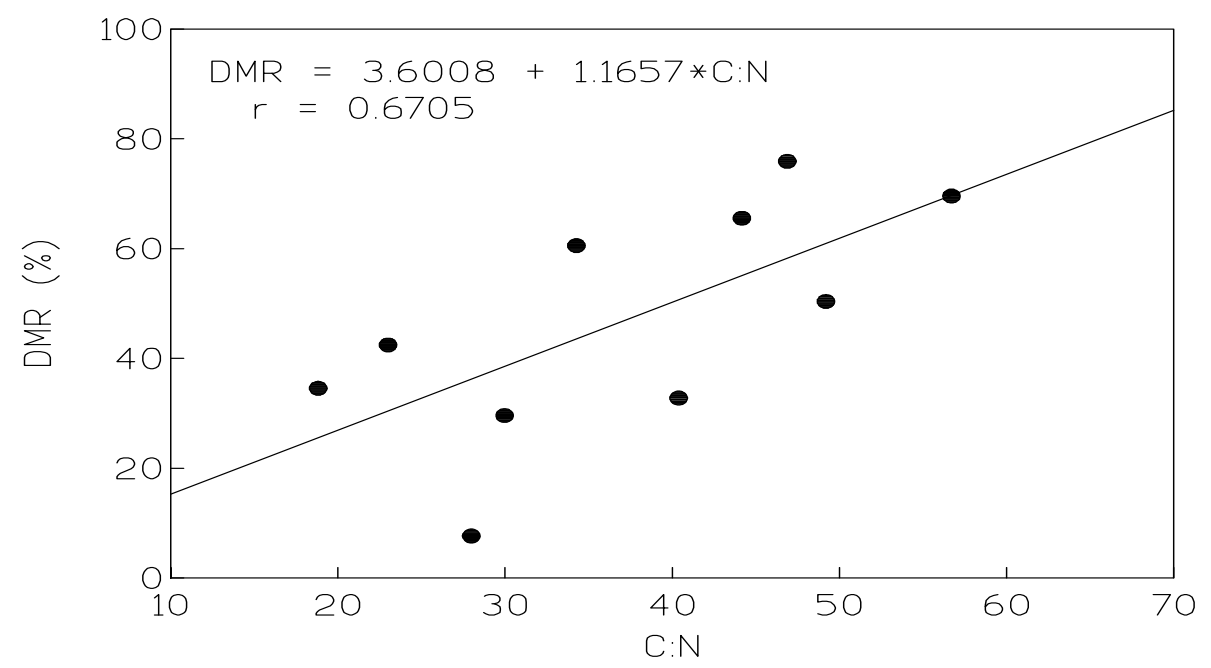

Figure 4: Relationship between DMR (\%) 23 weeks after incubation in situ and C:N ratio of original leaf litter of 10 tree species in a tropical rainforest in southwest Cameroon.
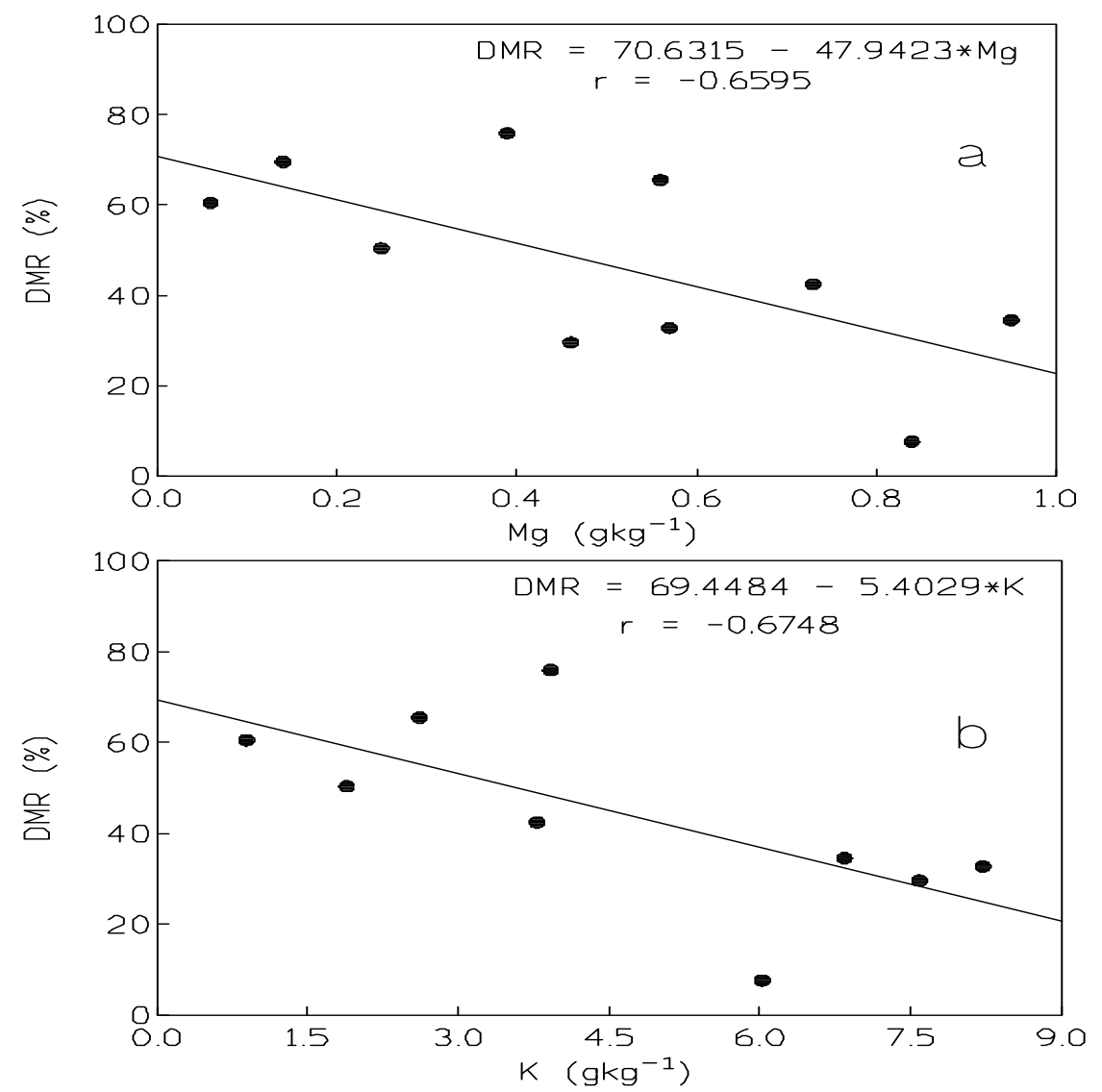

Figure 5: Relationships between DMR (\%) 23 weeks after incubation in situ and Mg (a), and K (b) original litters of nine tree species in Ebom rainforest, southwest Cameroon. 

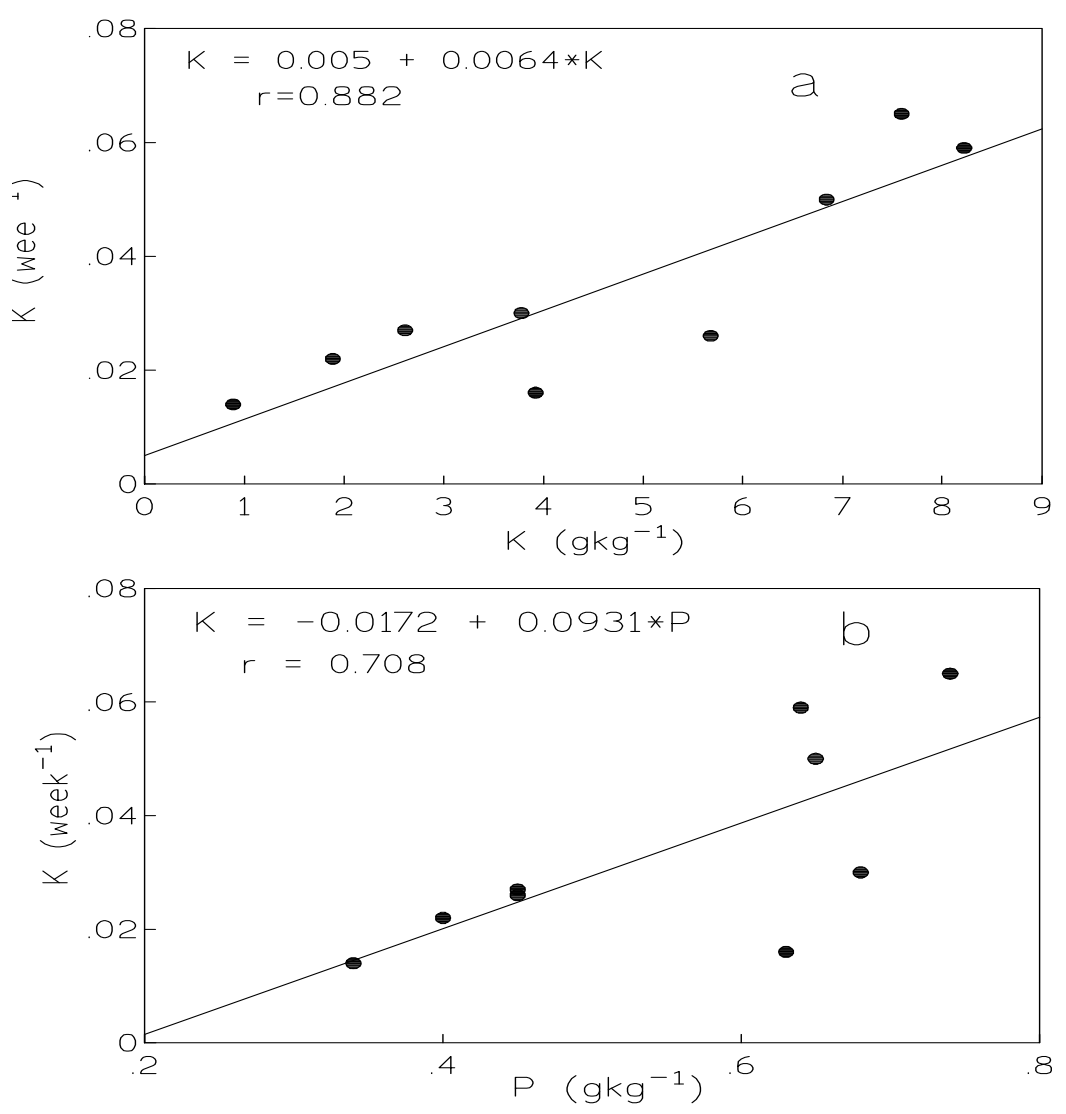

Figure 6: Correlation between litter decay constants (k) and $\mathrm{K}(\mathrm{a})$, and $\mathrm{P}(\mathrm{b})$ of original litters of nine tree species in Ebom rainforest, southwest Cameroon.

\section{DISCUSSION}

\section{Litter decomposition processes}

Litter decomposition varied among forest types and species composition (Table 4). Indeed, van Dam (2001) reported that mass loss of Chlorocardium rodiei litter at 230 days of incubation (about 33 weeks) in the field decomposition in Guyana tropical rainforests, developed on similar soil types (oxisols/ultisols) reached about $30 \%$ of their initial mass. according to Brouwer (1996), who worked in the same forests, this loss, for five species (Chlorocardium rodiei, Dicymbe altsonii, Eschweilera sagotiana, Eperua falcate and Eperua grandiflora) varied between $24 \%$ and $55 \%$ after 5 months (about 22 weeks) of field incubation, while Zou et al. (1995) found that the litter mass loss of 13 species ranged from 75.8 to $80.80 \%$ after 1 year of field incubation in the tropical rainforest of Puerto Rico. In our study the average litter mass loss varied significantly from 24.08 (E. utile) to $92.35 \%$ of initial mass ( $V$. grandifolia) after 23 weeks of litter incubation in situ. These values were from the middle to upper part of the range reported in the literature and showed wide spectra of litter mass loss in Ebom tropical rainforest. In the tropical rainforest, the litter decomposition constant varied from 0.21 to 5.50 year $^{-1}$ (Table 4). Moreover, Brouwer (1996) claimed on the basis of results obtained by BernhardReversat (1972) that the rate of litter decomposition in the African tropical rainforest was faster than that of other tropical rainforests. The results of our 
study showed that the decomposition rate constants of leaf litter were in the middle to highest part of the range reported in the literature (Table 4), and partly confirmed the conclusion of Brouwer (1996). In fact, in the present study the decomposition rate constants (k) varied from 0.73 to 8.58 year $^{-1}$, with an average value of 2.46 year $^{-1}$. Similar to the mass loss, the decomposition constants (k) had wide spectrum in Ebom tropical rainforest. This wide spectrum of litter decomposition could play an important role in the adaptation mechanism of this forest to eventual and environmental changes, due to natural or anthropogenic pressures. Among plant species, $V$. grandifolia exhibited the highest mass loss and decomposition rate constants, $M$. cecropiodes and E. utile had the lowest decomposition rate constants, while the other plant species showed intermediate behaviour. $M$. cecropioides and $X$. aethiopica, more particularly $M$. cecropioides, are pioneer species that characterize degraded zones (forest gaps, sides of routes) where nutrients are probably low, exhausted by leaching or land uses.

These species belong to the XylopiaMusanga community that insures the transition between Macaranga-Chromolaena community of degraded forest zone and an old secondary forest. Xylopia - Musanga community developed 5 to 6 years after fallow or logging and is insensible to soil variations and land use systems (van Gemerden and Hazeu, 1999). Conversely, the other species belong to the shade species that are dominant in climax forest.

The results found in our experiment globally differed from those reported in the tropical forest, but contradicted those of Mesquita et al. (1998), who reported that decomposition of leaf litter of pioneer species was slower than that of climax species. Indeed, the differences in the litter decomposition between pioneer and climax species are consistent with the results reported by Brouwer (1996), van Dam (2001) and Mesquita et al. (1998).
In contrast to Mesquita et al. (1998) finding, all the other authors showed that litter decomposition of pioneer species can be much more faster than that of climax species. Thus van Dam (2001), in tropical rainforests developed on infertile soil, reported that litters from pioneer species such as Goupia glabra were almost completely decomposed after 1 year of incubation, while the firm leaf litter of the climax species like Chlorocardium rodiei had only 52\% mass loss after 1 year in gap forest. According to the same author, the physical characteristics of the litter of the two species explained the difference between them. Contrary to $G$. glabra leaves, the smooth leathery surface of the firm and thick $C$. rodiei leaves provide a strong physical barrier against soil organisms attack and mycorrhiza infection. Our results have shown that the differences in litter decomposition among species in tropical rainforest was due not to difference between species groups (pioneer vs climax species), but partly to differences between the chemical characteristics of initial litter (Figures 4, 5 and 6). In fact, significant correlation between DMR and $\mathrm{C}: \mathrm{N}, \mathrm{Mg}$ and $\mathrm{K}$ or decomposition rate constants $(\mathrm{k})$ and $\mathrm{K}$ and $\mathrm{P}$ were found. This means that litter decomposition processes in the Ebom rainforest were influenced by nutrient contents as reported in the literature for rainforest ecosystems (Brouwer, 1996; Xu et al., 2004).

\section{Patterns of nutrient release}

Nutrient release showed different patterns. This release after 23 weeks of incubation was arranged in the following order: $\mathrm{K}>\mathrm{Ca}>\mathrm{Mg}>\mathrm{N}>\mathrm{P}$. The order of nutrient release was similar to results reported from previous studies in the tropical rainforest, with the exception that $\mathrm{Mg}$ was often released faster than $\mathrm{Ca}$, and $\mathrm{P}$ faster than N (Brouwer, 1996). Other studies have shown that $\mathrm{Mg}$ was also released faster than K (Songwe et al., 1995). Van Dam (2001) has observed a strong release of $\mathrm{Na}$ than $\mathrm{K}$ from the litter after 230 days (33 weeks) of incubation in Guyana rainforest and this could partly be explained by very wet climatic conditions due to the El Niño 
events.

The patterns of $\mathrm{N}$ and $\mathrm{P}$ were similar to most results reported in the literature and their immobilization indicated that leaching has no significant effect on their release compared to that of $\mathrm{K}$ and $\mathrm{Ca}$ that have a high potential of leaching. The low relative release of $\mathrm{N}$ and $\mathrm{P}$ can be explained by the fact that $\mathrm{C}: \mathrm{N}$ and $\mathrm{C}: \mathrm{P}$ ratios were generally greater in decomposer organisms than in plant tissues (Gosz et al., 1973). In forest developed on highly weathered soils, as in our study area, the litter acts as a sink of $\mathrm{N}$ and $\mathrm{P}$ because of the shortage of these nutrients (Songwe et al., 1995). The immobilization of these nutrients in the litter has been considered as a nutrient- conservation mechanism in some tropical ecosystems (Stark and Jordan, 1978).

In the studied forest, the release of nutrient expressed as percentage of initial content were in the middle to faster part of the range reported in others tropical rainforest in infertile soils, except for $\mathrm{N}$ and $\mathrm{Na}$ (Chacón and Dezzeo, 2007; Brouwer, 1996; van Dam, 2001). In fact, the nutrient release varied from 12 to $60 \%$ of initial content for $\mathrm{Ca}$, from 14 to $72 \%$ for $\mathrm{Mg}$, from 40 to $92 \%$ for $\mathrm{K}$ and from 2 to $70 \%$ for $\mathrm{P}$. Compared to our results, $\mathrm{Na}$ was highly released (90-92\%) from litter as reported by Brouwer (1996) and van Dam (2001) in the tropical rainforest of Guyana. No release of $\mathrm{N}$ was observed for 5 months of litter decomposition in the tropical rainforest of Guyana (Brouwer, 1996) and Venezuela (Chacón and Dezzeo, 2007). Since all the studies were carried out on infertile soils (Oxisols/Ultisols), the differences between the tropical rainforests might partly be explained particularly by differences in chemical properties of the initial litters, resulting from differences in the specific composition among forests, such as climatic conditions generated by some events like El Nino (van Dam, 2001). Among species, release of all nutrients was the highest in $V$. grandifolia, while the lowest was found in P. africana, $S$. scheffleri, K. gabonensis and X. aethiopica according to nutrient; and the other species presented intermediate behavior. These results suggest that the tropical rainforest of Ebom is characterized by high spectrum of nutrient release and immobilization, and this wide spectrum is a possible mechanism of adaptation to poor environment in nutrients.

In the tropical rainforest of Ebom, the fastest litter decomposition in situ, in general, was in $V$. grandifolia, the lowest being in $M$. cecropioides and E. utile, and the intermediate in other plants species. The nutrient release was also the highest in $V$. grandifolia, reaching sometimes $99 \%$ of losses compared to the initial values, the lowest in $P$. africana for $\mathrm{P}$, in $S$. scheffleri for $\mathrm{N}$ and $\mathrm{Mg}$, in $K$. gabonensis for $\mathrm{Ca}$ and $\mathrm{K}$ and in $X$. aethiopica for $\mathrm{Na}$, and intermediate in other species. Litter decomposition process was influenced by the chemical characteristics of initial litter. These results suggest that the rate constant of litter decomposition of the pioneer species was ranged among the lowest and climax species have a wide spectrum of decomposition process. They also suggest that the litter decomposition process was not related to species groups (pioneer $v s$ climax species, etc.), but partly to differences among chemical characteristics of litter.

\section{ACKNOWLEDGEMENTS}

This work was done in the Tropenbos Cameroon Programme for sustainable management forest of south west of Cameroon, with financial support of the European commission. The authors thank M.A.B. Ayangma, C. Kana, M.M. Mva and M. Mimbila for their field and laboratory assistance and the International Foundation for Science (IFS), Stockholm, Sweden and United Nation University (UNU), Tokyo, Japan, for their help in material through a grant to M. Adamou IBRAHIMA and also to technicians of the Laboratoire des Sols et de l'Environnement of the University of Dschang, Cameroon for their help in chemical analysis. 


\section{REFERENCE}

Begon M, Harper JL, Townsend CR. 2005. An Introduction to the Ecological Relations between Organisms and their Environments at the Ecosystem and Community Levels of Organization. Topics Include Primary Production and Decomposition, Migration and Dispersal Across Landscapes, and Food Webs. Blackwell Publishers: Oxford, UK; $1068 \mathrm{p}$.

Berg B, Laskowski R. 2006. Litter decomposition: a guide to carbon and nutrient turnover. Advances in Ecological Research, 38: 1-12.

Bernhard-Reversat F. 1972. Décomposition de la litière de feuilles en foret ombrophile de basse Côte d'Ivoire. Oecologia Plantarum, 7: 279-300.

Bockheim JG, Jepsem EA, Heisey DM. 1991. Nutrient dynamics in decomposing leaf litter of four tree species on a sandy soil in Northwestern Wisconsin. Canadian Journal of Forestry Research, 21: 803-812.

Bocock KSO, Gilbert CK, Capstick DC, Twinn JS, Woodman J. 1960. Changes in leaf litter when placed on the surface of soils with contrasting humus types. I. Losses in dry weights of oak and ash leaf litter. Journal of Soil Science, 11: 1-9.

Brouwer LC. 1996. Nitrogen cycling in pristine and logged tropical rainforest. Tropenbos - Guyana Series 1, Tropenbos-Guyana Programme, Georgetown, Guyana.

Chacon N, Dezzeo N. 2007. Litter decomposition in primary forest and adjacent fire-disturbed forests in the Gran Sabana, southern Venezuela. Biology and Fertility of Soils, 43: 815-821.

Cisneros-Dozal LM, Trumbore SE, Hanson PJ. 2007. Effecf of moisture on leaf litter decomposition and its contribution to soil respiration in a temperate forest. J. Geophysical Research, 112: 10-13.

Cuevas E, Medina E. 1988. Nutrient dynamics within Amazonian forest II Fine root growth, nutrient availability and leaf litter decomposition. Oecologia, 76: 222-235.

Didham KR. 1998. Altered leaf-litter decomposition rates in tropical forest fragments. Oecologia, 116: 397-406.

Eba'a Ayeti R. 2000. TROPFOMS, a decision support model for sustainable management of rainforest. TropenbosCameroon Series 2, The TropenbosCameroon Programme, Kribi, Cameroon.

Edmonds RL. 1984. Long-term decomposition and nutrient dynamics in Pacific silver fir needles in Western Washington. Canadian Journal of Forestry Research, 9: 395-400.

Foahom B, Jonkers WBJ. 1992. A Programme for Tropenbos Research in Cameroon. Final report. The Tropenbos Fondation, Wageningen, The Netherlands.

Franqueville A. 1973. Atlas régional SudOuest I, République du Cameroun. ORSTOM, Yaoundé, Cameroun.

Gosz JR, Llkens GE, Bormann FH. 1973. Nutrient release from decomposing leaf and branch litter in the Hubbard Brook Forest, New Hampshire. Ecological Monography, 43: 173-191.

Hirobe M, Sabang J, Bhatta BK, Takeda H. 2004. Leaf-litter decomposition of 15 tree species in a lowland tropical rain forest in Sarawak: decomposition rates and initial litter chemistry. Journal of Forestry Research, 9: 341-346.

Hobbie SE, Vitousek PM. 2000. Nutrient limitation of decomposition in Hawaiian forests. Ecology, 81: 18671877.

Ibrahima A, Ntonga JC, Mvondo Ze A. 2010. Leaf litter decomposition in tropical rainforest of Ebom, Southwest Cameroon: comparison among guild classes. Tropical Ecology, 51(2): 247254.

Ibrahima A, Schmidt P, Ketner P, Mohren 
GJM. 2002. Phytomasse et cycle des nutriments dans la forêt tropicale dense humide du sud Cameroun. Tropenbos - Cameroon Documents 9, $150 \mathrm{p}$.

Ibrahima A. 1995. Approches expérimentale et spectroscopique de la décomposition de litières méditerranéennes. Doctorat de l'Université de Montpellier II, Montpellier, France, 185p.

Johnson DW, Gessel SP, Grier CC, Richards BN, Vogt KA. 1982. Nutrient cycling in the Pacific Northwest. In Analysis of Coniferous Forest Ecosystems in the Western United States. Edmonds RL, Hutchinson R. (eds). Publishing Co.: Stroudsburg, PA.

Kimmins JP. 1987. Forest Ecology. Macmillan Publishing Company.

Knops JMH, Wedin D, Tilman D. 2001. Biodiversity and decomposition in experimental grassland ecosystems. Oecologia, 126: 429-433.

Leigh EG, Davidou P, Kick CW, Puyravaud J-P, Terborgh J, Ter Steege H, Wright SJ. 2004. Why do some tropical forests have so many species of trees? Biotropica, 36: 447573.

Letouzey R. 1985. Notice de la carte phytogéographique du Cameroun au 1: 500,000. Institut de la Carte Internationale de la Végétation, Toulouse, France.

Mayer PM. 2008. Ecosystem and decomposer effects on litter dynamics along and old field to old-growth forest successional gradient. Acta Oecologica, 33: 222-230.

McGroddy ME, Silver WL, De Oliveiro RC. 2004. The effects of phosphorus availability on decomposition dynamics in a seasonal lowland Amazonian forest. Ecosystems, 7: 172-179.

Medina E, Cuevas E. 1989. Patterns of nutrient accumulation and release in
Amazonian forests of the upper Rio Negro basin. In Mineral Nutrients in Tropical Forest and Savanna Ecosystems, Proctor J (ed): Blackwell: Oxford.

Mesquita R, Workman SW, Neely CL. 1998. Slow litter decomposition in a Cecropia-dominated secondary forest of central Amazonia. Soil Biology \& Biochemistry, 30: 167-175.

MINFOF. 2005. Evaluation des ressources forestières nationales du Cameroun : 2003-2004. Unité Technique du projet d'Inventaire Forestier National en collaboration avec la FAO, MINFOF, Yaoundé, Cameroun, 90 p.

Negrete-Yankelevich S, Fragoso C, Newton AC, Russell G, Heal OW. 2008. Species - Specific characteristics of trees can determine the litter macroinvertebrate community and decomposition process below their canopies. Plant and Soil, 307: 83-79.

Nounamo L, Yemefack M. 2001. Farming systems in the evergreen forest of southern Cameroon: shifting cultivation and soil degradation. TropenbosCameroon Documents 8, The Tropenbos-Cameroon Programme, Kribi, Cameroon.

Ntonga JC, Watterloo MJ, Ayangma AB. 2002. Hydrology, erosion and nutrient cycling in a forest ecosystem in southern Cameroon. TropenbosCameroon Documents 10, The Tropenbos Cameroon Programme, Kribi, Cameroon.

Olivry JC. 1986. Fleuves et rivières du Cameroun. Collection Monographe Hydrologiques d'ORSTOM $\mathrm{N}^{\circ} 9$. MESRES-ORSTOM, Paris, France.

Olson JS. 1963. Energy storage and the balance of producers and decomposers in ecological systems. Ecology, 44: 322-331.

Proctor J, Anderson JM, Fogeden SCL, Vallack HW. 1983. Ecological studies in four contrasting lowland rain forest in Gunung Mulu National Park, Sarawak: II. Litterfall, litter standing 
crop and preliminary observations on herbivory. Journal of Ecology, 71: 261-283.

Sokal JR, Rohlf RR. 1981. Biometry ( $2^{\text {nd }}$ edn). Freeman and Co: San Francisco, USA.

Songwe NC, Okali DUU, Fasehun FE. 1995. Litter decomposition and nutrient release in a tropical rain forest, Southern Bakundu forest Reserve, Cameroon. Journal of Tropical Ecology, 11: 333-350.

Stark NM, Jordan CF. 1978. Nutrient retention by the root mat of an Amazonian rain forest. Ecology, 59: 434-437.

Sun J, Campbell J, Law BE, Wolf V. 2004. Dynamics of carbon storage in soil and detritus across chronosequences of different forest types in the PacificNorthwest USA. Global Change Biol., 10: 1470-1481.

Valenzuela-Solano C, Crohn DM. 2006. Are decomposition and release from organic mulches determined mainly by their chemical composition? Soil Biology \& Biochemistry, 38: 377-384.

van Dam O. 2001. Forest filled with gaps: effects of gap size on water and nutrient cycling in tropical rainforest. A study in Guyana. Tropenbos-Guyana Series 10, Tropenbos-Guyana Programme, Georgetown, Guyana.
Van Dijk JFW. 1999. Non-timber forest products in the Bipindi - Akom II region, Cameroon: a socio-economic and ecological assessment. TropenbosCameroon Series 1. The TropenbosCameroon Programme, Kribi, Cameroun.

Van Gemerden BS, Hazeu GW. 1999. Landscape ecological survey $(1: 100,000)$ of the Bipindi -Akom IILolodorf region, southwest Cameroon. Tropenbos-Cameroon Documents 1. The Tropenbos-Cameroon Programme, Kribi, Cameroun.

Xu X, Hirata E, Enoki T, Tokashiki Y. 2004. Leaf litter decomposition and nutrient dynamics in a subtropical forest after typhoon disturbance. Plant Ecology, 173: $161-170$.

Zou X, Zucca CP, Waide RB, McDowell WH. 1995. Long-term influence of deforestation on tree species composition and litter dynamics of Tropical rain forest in Puerto Rico. Forest Ecology \& Management, 78: 147-157. 